\author{
RAJSLI Ilona \\ Újvidéki Egyetem, Bölcsészettudományi Kar \\ Magyar Nyelv és Irodalom Tanszék \\ Újvidék \\ rajsli@stcable.net
}

\title{
BÁCSKAI VONATKOZÁSOK MARGALITS EDE KORAI FRAZÉMAGYÜJTEMÉNYÉBEN
}

\author{
Traits of the Bácska Region in Ede Margalits's \\ Early Collection of Phrasemes
}

\section{Motiv Bačke u prvoj zbirci frazeoloških izraza Edea Margaliča}

Margalits Ede Bácskai közmondások és szólásmódok című gyüjteménye 1877-ben jelent meg Baján, s ez a kiadvány a szerző későbbi monumentális szóláskiadványainak az úttörője is egyben. Ez a korai kis szólástár jelzi a frazémák gyűjtése felé forduló Margalits szakmai-tudományos attitűdjét. A szerző a bevezetőben közli a számára releváns gyűjtési és szerkesztési elveket, ugyanakkor körvonalazza egy országos szintü gyűjtemény vízióját is. A későbbi adattárak gyakorlatától eltérően e korai kiadványban még szoros betürendben sorakoznak a szólások, így vezérszavak sincsenek. Tanulmányunkban e bácskai frazémakiadvány bemutatásán keresztül a területi kötődésű szólásokban előforduló lokális jegyek kiemelésére törekszünk: amilyen a nyelvjárási jelenségek, a tájszavak előfordulása, a toponimák felbukkanása a szólásokban, a tájhoz kötődő anekdotikus frazémák jelenléte, az etnosztereotípiák sokszínúsége. Erdélyi János gyakorlatához hasonlóan Margalits is gyakorta füz magyarázatot a kevésbé ismert frazémákhoz, a helyi vonatkozású szólásanyag esetében pedig a frazémát indukáló (valós vagy vélt) történetet is közli, számos igen értékes - területi kötődésü - adomával gazdagítva a vidék hely- és müvelődéstörténetét. Kulcsszavak: frazéma, diakrón frazeológia, területi kötődés, Bácska, Margalits Ede

\section{Bevezetés}

Margalits Ede szerteágazó tevékenysége a XIX. és a XX. század fordulójának évtizedeiben teljesedett ki. Az elérhető életrajzi adatokból megtudhatjuk, hogy a zágrábi születésü (1849) Margalits Bécsben bölcsészettudományt, 
Párizsban pedig összehasonlító irodalmat tanult. 1871-től Baján gimnáziumi irodalomtanár, majd Zomborban gimnáziumi igazgató lett, s az ottani kulturális élet egyik jeles egyéniségének számított (vö. Bene 2004, 206). 1875-ben Budapesten bölcsészdoktori oklevelet szerzett, $\mathrm{s}$ egyetemi tanárként - a horvát nyelv és irodalom oktatójaként - tevékenykedett egészen nyugdíjba vonulásáig (1915), amikor ismét visszatért Zomborba. ${ }^{1}$ Számos irodalomtörténeti és történelmi tárgyú tanulmányt jelentetett meg, fordított horvát és szerb nyelvü müveket, készített horvát-magyar és magyar-horvát zsebszótárt, horvát történeti repertóriumot, ám munkásságának leginkább értéktartó részét frazémagyüjtő munkássága képezi, mellyel az 1860-as évektől folyamatosan foglalkozott. A gyüjtömunka eredményeit folyamatosan közzé is tette, már 1878-ban publikált a Magyar Nyelvőrben Latin-magyar közmondások címmel. Az úttörőnek minősíthető 1877-es Bácskai közmondások és szólásmódok címü kis kötete után 1895-ben elöször a Florilegium proverbiorum universae Latinitatis ${ }^{2}$ címü gyüjteménye jelent meg, amely - harmincévnyi gyüjtés eredményeként - mintegy tizenháromezer, a latin nyelvben meglevő közmondást, szólást, szentenciát tartalmaz. ${ }^{3}$ Ám e tevékenységének a köréből föként a hatalmas címszóállományú, mintegy húszezer szólást tartalmazó Magyar közmondások és közmondásszerü szólások című kötete az igazán ismert. Ez a kötet 1896-ban jelent meg a Magyar Tudományos Akadémia és a Kisfaludy Társaság támogatásával. Örvendetes módon a kissé már háttérbe került művet 1990-ben az Akadémiai Kiadó reprint sorozata újra a köztudatba emelte.

\section{Margalits korai frazémagyüjteményéröl}

Margalits korai frazémagyüjteménye, a Bácskai közmondások és szólásmódok címü kis kötet, amely 1877-ben Baján jelent meg, még inkább feledésbe merült. Feltételezhetően ez egyrészt a kiadás helyének tudható be, másrészt pedig a gyüjtemény szük, helyi jellegének. Az 1896-os szólásgyüjtemény bevezetőjében Margalits kifejezi azt a szándékát, hogy a korábbi gyüjtés eredményei

\footnotetext{
${ }^{1}$ Margalits halálának zombori helyszíne Gulyás Pál írásában meg van kérdőjelezve. Mind a Kalapis-féle Életrajzi kalauz II. (Forum Könyvkiadó, Újvidék, 2003), mind pedig az internetes források Budapestet jelölik meg.

2 A továbbiakban Florilegium.

${ }^{3}$ E gyüjtemény utóéletéhez tartozik, hogy 2014-ben a Tinta Könyvkiadó gondozásában megjelent a Florilegium átdolgozott és bővített változata Kovács Erzsébet szerkesztésében, Magyarlatin közmondásszótár címmel. Kétezer magyar közmondás, szólás klasszikus és újkori latin megfelelö-jét tartalmazza.
} 
is beépüljenek az összegző nagy munkába. ${ }^{4} \mathrm{~A}$ bácskai provenienciájú szólásgyüjteményt Margalits Türr Istvánnak ajánlotta, akit „Baja és Bács legnagyobb szülötteként" tisztelt. A 46 oldalas füzet rövid (cím nélküli) bevezetőt tartalmaz, melyből tisztázható a szerző kutatói-szakmai attitüdje: az őt megelőző szólásgyüjtők munkájához való hozzáállása, valamint a kortársak teljesítményének a minősítése. A nép ajkán élő nyelvi kincs gyüjtését így indokolja:

Az irodalom figyelme körülbelül három évtizede a nép felé fordul, hogy a már-már, külföldi antik és modern befolyások alatt, nemzeti szinét és életét vesztő nyelvnek ujra eredeti tős-gyökeres magyar zománcát visszaadhassa: a nyelvbuvárok a nép szellemtengerébe merülnek és abból a népdalok és közmondások gyöngyszemeit gyüjtik össze, hogy igy lassanlassan a külföldről kölcsönzött hamis nyelv-ékköveket kiszoríthassák (5).

A népdalgyüjtés területén Kriza Jánost, Erdélyi Jánost, Aigner Lajost ${ }^{5}$ emeli ki, ám a közmondásgyüjteményekről kialakított véleménye meglehetősen szubjektív. Ma már igencsak elfeledett szerzők - Kovács Pál, Szirmay Antal, Noszkó Alajos - munkáit emeli ki, tartja „korlátaik ellenére is” becsesnek, Dugonics András 1820-ban megjelent gyüjteményét hasznosnak ugyan, de ,rendezetlennek" minősíti, ugyanakkor Ballagi Mór Magyar példabeszédek, közmondások és szójárások gyüjteménye címü múvét (Pest, $1850^{6}$ ) Margalits keményen bírálja, nagy teret engedve az akkoriban egyáltalán nem meglepő éles kritikai hangnak. Ballagi gyüjteményét még „anyagkészletként”, tehát adattárként sem tartja elfogadhatónak. Az Új Magyar Muzeum 1851. évi számában (II. füzet, 110-120.) jelent meg az a Ballagit bíráló kritika ${ }^{7}$, amelyből Margalits idéz, $\mathrm{s}$ amely véleményt ő is teljes egészében elfogad. E kritika hiányosnak tartja Ballagi gyüjteményét, és felrója, hogy sok esetben nem a nép által használt formát emeli be a szótárába. A könyvismertetőben vélhetően legsúlyosabbnak a „magyar népszellem elmásitása” számít.

Margalits a bácskai kisszótár bevezető szövegében a Ballagi-bírálat mellett egy teljes, „kellően rendezett” közmondásgyüjtemény szükségességét is felve-

\footnotetext{
${ }^{4}$ Megállapítható, hogy az 1896-os összegző gyüjtemény bevezetőjében ennek ellenére nem hivatkozik a bácskai gyüjteményre.

${ }^{5}$ Margalits szövegében Abafi-Aigner néven szerepel.

${ }^{6}$ Második kiadása 1855-ben.

${ }^{7}$ A Toldy Ferenc által szerkesztett akadémiai közlöny Irodalmi Napló rovatában a Könyvismertetések között található a terjedelmes és igen kemény hangú bírálat, alatta mindössze egy G. monogram van.
} 
ti, s Szarvas Gáborra hivatkozva egy országos szintü gyüjtemény kiadásának tervét vetíti elöre, mely „topographice is fogja az egyes közmondások használatát megjelelni, a variansokat felölelni és származásukat és értelmöket commentárral felvilágositani” (7). Margalits ezután a korabeli szólásgyüjtés elméleti és módszertani kérdéseiről is lejegyzi legfontosabb meglátásait, valamint vázolja azokat a gyüjtési és szerkesztési elveket, amelyek eredményeként egy országos szintủ gyűjtemény jöhetne létre. Ennek egyfajta mintafüzete tulajdonképpen a Bácskai közmondások és szólásmódok kötete, amely után egy befejező, második kötetet is bejelent.

(Tipológiai kérdések) Margalits az 1877-es szólásgyüjtemény bevezetőjében még nem foglalkozik a frazémák definiálásával, illetve a tipológia igen bonyolult kérdéskörével; ez a problematika csak később merül fel tanulmányaiban. A Nyelvtudományi Közlemények több számában jelennek meg tanulmányai és szólásgyüjtései $A$ magyar közmondások és szólások rostája címmel, ezekben jelzi azt a törekvését, miszerint a frazémák első használóit is igyekszik felkutatni; ez a gyakorlata a Magyar közmondások és közmondásszerü szólások címü kötetében érvényesül. 1910-ben a Florilegium kötetéhez kiegészítö, supplementum kötetet jelentet meg, melyben rendet próbál tenni a terminológiában és a frazémák csoportosítása terén. Visszautalva a Nyelvtudományi Közleményekben megjelent cikkekre, Kovács Erzsébet így minősíti Margalits munkásságának sikerességét:

Margalits Ede úttörő felismerése és [...] próbálkozásai ellenére, hogy a korábbi gyüjtemények terminológiai összevisszaságában rendet vágjon, és megkülönböztesse az állandósult szókapcsolatok, frazeológiai egységek eltérő fajtáit (szólások, közmondások, szóláshasonlatok, szállóigék stb.), ez a cikksorozat mégis vegyes anyagot tartalmaz (Kovács 2014, 6).

Margalits tipológiai törekvései tehát nem jártak sikerrel, a bácskai anyagban tapasztalható sokszínüség később is jellemző maradt.

Napjaink irányadó frazeológiai szakirodalmában azt az egybehangzó véleményt találjuk, hogy a polilexikalitás (a frazeológiai egységek legalább két vagy több szó kapcsolatai) és a lexikai rögzültség (a kifejezés elemei szókészleti egységet alkotnak, az alkotóelemek sorrendje és morfológiai felépítése nagyrészt kötött) az a két sajátság, amely a frazeológiai egységek vagy frazémák fogalmának körülhatárolásában és osztályozásában egyöntetü (Forgács 2007, 20). Margalits bácskai gyüjteményében az egyszavas frazémáktól a többmondatos szóláshasonlatokig, közmondásokig, wellerizmusokig minden típus fellelhető. A polilexikalitás kritériuma igen tág értelemben közelítendő meg, 
hiszen számos igei alakulat található: pl. Becsipett. ${ }^{8}$ Becsipték. Cigánykodik. Ezeket Hadrovics László olyan frazémaszerü igéknek nevezi, amelyek mindig is magukban álltak (vö. Hadrovics 1995, 28).

Forgács Tamás többféle lehetöséget is felvázol arra az esetre, amikor egy ige az állandósult szerkezet igei fejeként megmarad, akár jelentéstapadással (kivégez a világból $\rightarrow$ kivégez), akár szóképzéssel vagy szóösszetétel útján (baklövés $\leftarrow$ bakot ló). Ezeket a szakirodalomban egyszavas frazémának, monofrazémának, illetve frazeológiai alapú derivátumnak is nevezik (vö. Forgács 2007, 23). Margalits gyüjteményében számos olyan igei formát találunk, amely mai értelemben már nem tartozik a frazémák közé, pusztán metaforikus értelme révén kapcsolódik hozzájuk: pl. Berúg-kirúg. Cigánykodik. Kakaskodik. Rápörköltem.

Melléknévi funkciójú, egyszavas „monofrazéma” a Kolompos, jelentését Margalits nem közli, de átvitt értelme révén ide sorolja. Felveszi frazémajegyzékébe a következő melléknévi funkciójú összetételeket is: Madárijesztő. Köpönyegforgató. Randaszájú. Napraforgó. A kéttagú szerkezetek között akadnak birtokos szerkezetek: Akasztófa virága. (Ez később összetétellé válik $\rightarrow$ akasztófavirág.) Apja fia. Számos jelzős szerkezet is található: Álmos táska. Bácskai bugris. Bécsi kofa. Csipet urfi-s közéjük Margalits igen meglepő módon névalakulatokat is besorol: Toldy Miklós. Babszem Jankó. Borsszem Jankó. A következö adatban mintha két címszó került volna egymás mellé: Baka, pocsétakerülö ${ }^{9}$ - ez a szerkezet feltételezhetően ilyen formában érkezett az adatközlőktől; a későbbi adattárban már csak a pocséta címszó alatt találjuk meg ezt a szólást, mégpedig táji változatban: Pocsolyakerülő. (Baka). ${ }^{10}$ Az egyszerü mondat formájú frazémák között is eltérő az idiomatikusság mértéke: Beköpte a légy. Csapja a levet. Csunyául megjárt. Átlát a szitán. A gyüjteményben egy wellerizmus (szólásidézet) is előfordul, itt a szólás tartalmát kommentáló „véleményvezér” nem lehetett feltétlenül helyi, közismert személy, mert a szólás ritmikussága, felépítésének rímszerü egybecsengése más értelmezést sugall: A hol nincs ott ne keress, azt mondja Pál szekeres. Forgács Tamás határesetként az ún. epikus proverbiumok közé sorolja a wellerizmust (Forgács 2007, 22), Margalitsnál a történetnek már csupán a csattanója lelhető fel, valamint a szólásegész parodizáló, ironizáló hangneme.

\footnotetext{
${ }^{8}$ A Margalits-gyüjteményből idézett frazémák helyesírásán, írásképén nem változtattunk, az idézett példákat dőlt betükkel jelöltük. Mivel a frazémák a gyüjteményben a szólások kezdőbetüje szerinti ábécérendben szerepelnek, idézéskor az oldalszám közlésétől eltekintettünk.

${ }^{9}$ Régen a gyalogos katona tréfás megnevezése volt.

${ }^{10} \mathrm{Az}$ adat forrásaként Erdélyi János művét jelöli meg.
} 
Margalits azokat a kiszólásszerü, a kommunikációs helyzethez szorosan kötődő kliséket is felvette adattárába, amelyek a helyzetmondatokhoz állnak legközelebb: Mire nézed a napot. Ujság a hasamba, hideglelés pokolba ${ }^{11}$ Más folklórtermékekből vagy irodalmi mủvekből származó átmeneti típusokat is találunk: Aki engem nem szeret, egye meg az egeret - ami egy lakodalmi rigmus variánsa, de előfordul népdaltöredék is: Lám megmondtam Angyal Bandi ne menj az Alföldre.

\section{Bácskai vonatkozások}

Papp György a vajdasági frazeológiai korpuszt áttekintő tanulmányában kiemeli a helyi jellegű szólások gyüjtésének, adatolásának a fontosságát: „Számunkra a legnagyobb értékkel bírnak az eredeti területi kötődésű szólások, közmondások, vagy az általános frazeológiai formák földrajzi kötődésü redakciói” (Papp 2007, 95 - P. Gy. kiemelése). Margalits gyüjteményében változatos típusú szóláscsoportban lelhető fel ilyen táji vonatkozás, jelzős szerkezetben: Bácskai bugris; szóláshasonlat formájában: Helyén van, mint Dorozsma. Szépen iszik, mint a szabadkai ember; sőt egy történet vagy mese záróformulájában is: Itt a vége, tedd a jégre, csúszszál vele Báttaszékre.

(Toponimák a szólásokban) A Bajához közeli falvak, helyek gyakran megjelennek az összegyüjtött frazémákban, ezeknél a szerző lapalji jegyzetben utal az illetö falu helyére: pl. Kurta mint a szeremlei szoknya. (Falu Bajához közel.) ${ }^{12}$ Lop mint a madarasi ember. (Falú Bácskában.) Hasonlóak még: Maga iszik, mint a csonoplai tamburás. Világnak szaladt, mint a miskei malac. ${ }^{13}$ Megjegyezhetjük, hogy ezek a frazémák kivétel nélkül szóláshasonlatok.

A régió városai, falvai mellett a mikrotoponimák ritkábban fordulnak elő, de erre is van példa: A ki egyszer a Sugovica vizéböl ivott, visszajö Bajára. ${ }^{14} \mathrm{~A}$ Sugovica fontos víznév a Baja környékiek számára. Pesty Frigyes nemcsak lokalizálja ezt a Duna-ágat, hanem a víznév etimológiájával is próbálkozik: „A Dunának, közvetlenül Baja városa alatt folyó ágát, mely az érintett Pandur sziget keleti oldalát körülfogja »Sugovicza« név alatt ismerjük. Tulajdonképeni ne-

\footnotetext{
${ }^{11}$ Itt lapalji jegyzetben Margalits is jelzi, hogy egy „mondókáról” van szó, amit az új gyümölcs evésekor mondanak.

${ }^{12}$ Ezeket a lapalji megjegyzéseket zárójelben, dőlt betükkel közöljük.

${ }^{13}$ Itt Margalits a lábjegyzetben hozzáteszi: (Falú Bajához közel.)

${ }^{14} \mathrm{E}$ szólás táji változataiban cserélődik a víznév: pl. Ki a Tisza vizét issza, vágyik annak szive viszsza. (Vö. O. Nagy Gábor 1982.)
} 
ve Sugárviz, mely a dalmát nép által lassanként »Sugoviczára « változtatott" (Köhegyi-Solymos 1973, 19). Erre a víznévre még egy frazémában utal: Elmentoda, hol a part szakad. Margalits a lapalji értelmezéssel Baja környékére lokalizálja a szólást: (Veszedelmét keresi. Baján a rosz házak a Sugovica partján vannak.).

Számos szólásnak a Duna a kulcsszava, közöttük vannak ritkább formák, amelyek csak e folyó említésével ismeretesek: pl. Ezt a Duna sem mossa le róla. Ez annyi, mint pénzt a Dunába vetni. Fühöz-fához kapkod, mint a Dunába haló ember. Más szólások esetében a tájegységnek megfelelően a Tisza folyó is helyettesíthetö: Dunába/Tiszába vizet hordani. Meglesz majd, ha a Duna/ Tisza visszafelé foly.

A falu-, illetve területcsúfolók típusa felé mutat az inkább szójátékra épülö Bajának sok a baja szólás, valamint a Bácskai bugris ${ }^{15}$ szerkezet. Ez utóbbi a későbbi gyüjteményben a bugris címszó alatt található, egy tájegység-csúfolóba beépítve: Baranyai tarisznyás, somogyi bicskás, bácskai bugris. A szerző a kibővített változatot Sirisaka Andor gyüjtésének tekinti.

A többtagú szólásalakulatokban (Papp György terminusával: szólássorolókban) a fontosabb régióbeli városok egész sora jelenik meg: A kit Baján megnem szólnak, Szabadkán le nem itatnak, Zomborban megnem vernek, Ujvidéken roszra nem visznek, az elmehet az egész világon, sehol rajta ilyesmi meg nem esik. A szólássoroló szerves összetevője a lábjegyzetben található kommentár, amellyel Margalits azt kívánja jelezni, hogy jártas a nemzetközi szólásanyag tipológiai kérdéseiben, hiszen az említett frazémasornak a szélesebb kontextusú változatát is közreadja: (E közmondás ép oly találóan jellemzi Bács föbb városait, mint azon olasz közmondás mely a két ${ }^{16}$ föbünt Olaszhon hét föbb városában szállásolja el: a kevélység Genuában, a fösvénység Florencben, az irigység Romában, a bujaság Velencében, a torkosság Milanóban, a harag Bolognában, a jóravalórestség Nápolyban lakik.).

(Nyelvjárási jellemzők) Margalits Ede a kor szellemének megfelelően törekszik a szólásanyag autentikus lejegyzésére. Már a bácskai anyag bevezetőjében, a Ballagi-bírálatban is ostorozza azokat, akik ,eredeti formájokból kivetkeztetve s elcifrázva, elmagyartalanitva" adják közre a szólásokat, közmondásokat, akik tehát egyrészt nem az eredeti ejtés, táji változat szerint közlik, másrészt az egyes frazémákat önkényesen átformálják, elferdítik. A szóláskincs nyelvjárási szempontjainak a kérdéseivel régóta foglalkoznak a kutatók. O. Nagy

\footnotetext{
${ }^{15}$ A szó etimológiailag a német Buger 'paraszt' szóval mutat kapcsolatot, melléknévi 'ostoba', illetve fönévi 'faragatlan ember' jelentése már az 1830-as években használatos volt.

${ }^{16}$ Itt feltehetően nyomtatási hiba van, a hét helyett a két szót találjuk.
} 
Gábor megállapítja: ,a nyelvjárási és a régi nyelvi kifejezések esetében semmi fogódzónk nincs annak a megállapításához, hogy a változatok közül melyiket tekintsük a másik rovására közlésre méltónak” (O. Nagy 1982, 22). A gyüjtők a hozzájuk közel álló, illetve az adatközlőktől nyert ejtésformát részesítik előnyben, így történhetett ez Margalits bácskai anyagánál is.

Mindemellett Margalits sem következetes a nyelvjárási jelenségek rögzítésében; előfordul a nyelvjárási változat ejtés szerinti lejegyzése: pl. A szegény csikorog, mint a kenyetlen kerék. Oda adná az üngét is. Fót hátán fót. Kápusztás kertbe néz. Minden tehén a maga bornyát nyalja. Ennek ellenére a frazémák zöme a korszak köznyelvét mutatja. Meglehetősen kevés tájszó jelenik meg, közöttük van jelentésbeli típusú: A pénz olvasva, az asszony verve jó, valamint valódi tájszó is felbukkan: Baka, pocsétakerülö. Ez a rendhagyó formájú frazéma a táji lexikai alakokból eredő variánsképződés jelenségére mutat rá: pocsolyakerülö pocsétakerülö. Előfordulhatott, hogy már az adatközlötöl alaki torzulással került a gyüjtőhöz valamely tájszó, nyelvjárási kifejezés: pl. Egész nap présmitál - a 'siránkozik' jelentésủ szót ekkor már prézsmitál formában használták (vö. Rajsli 2013, 8), s az ajándok forma is archaizmusnak számított már Margalits korában: A szép megköszönés, több ajándokra gerjesztés.

(Szóláscsúfolók) A szólásformájú csúfolók tömören, szemléletesen teszik a gúny tárgyává az egyes emberi magatartásformákat, foglalkozástípusokat, vallási vagy nemzeti hovatartozást (vö. Forgács 2007, 79). Ezeknek minden típusa fellelhető a gyüjteményben, egyedül a mesterségcsúfolók vannak kisebb számban: pl. Kicsi zsömle, kövér pék. Kovács a kovácsra irigykedik. Falucsúfolók: OMoravica, jaj Pacsér, átkozott Csantavér, kenyeretlen Bajsa. Itt a lapalji megjegyzésben hozzáteszi: (Bácskai falvak jellemzése.). A vallás- és etnikumcsúfolók közül jellemző példa az Olyan vastag nyakú, mint a kálusz. ${ }^{17}$ Ennek ellenpólusaként megjelenik a Pápista szinben van szólás is. A korpuszban számos etnosztereotip szólást találunk; több nemzetnév bekerül a frazémákba: pl. Ha a tótnak szállást adsz, még kiver a házból. Cifra mint a rác oltár. Csak ugy lityeg-lotyog, mint svábon a plundra. Búsul, mint a lengyel. Huncfut a német. A zsidó nem ád semmit a „volt"-ra.

A szólásformájú csúfolókhoz rövid epikus történet is járulhat, amely magyarázatként szerepel a lap alján: pl. a Mondj igazat, betörik a fejed frazémát a következő történet értelmezi: (Egy kis városban a passióénekben egy molnár volt a Krisztus, stoikus nyugalommal hallgatta ez mindazon szitkokat melye-

\footnotetext{
${ }^{17} \mathrm{Ez}$ a lexéma kizárólag az Új Magyar Tájszótárban lelhető fel, csak Baja környékéről adatolható a szó 'református' jelentésben.
} 
ket a pseudo-zsidók ellene szórtak, de midőn egy suszter inas hozzá lopódza „tisztlopónak” nevezte, ez már több volt a soknál, és a hangjegytartóval fejbe ütötte a csúfolódót. Innét e közmondás.).

Margalits helyenként sajátosan viszonyul a frazémákban felbukkanó nyelvi tabu kérdéséhez. Míg a korszak gyűjtőinél (Erdélyi, Ballagi stb.) az tapasztalható, hogy nevükön nevezik a dolgokat, Margalits egyféle szemérmesség, kímélet okán kipontozza a kerülendőnek ítélt szavakat: Fényes mint a Salamon ...; illetve más módon oldja meg: Fogadatlan prókátornak tudod mi a fizetése? Ez esetben kérdéssé formálja a frazéma második részét, ami tkp. annyi: ebszar a fizetése. Előfordulnak azonban olyan esetek, amikor nem tartja magát a saját eufemisztikus elvéhez: Kikopott mint ebszar a hóból. Lócsöcs a markodba.

(Lokális események, történések-helyi adomák, anekdoták) Egyes frazémák hátterében megtörtént események, történetek húzódnak meg, s az idő távlatából már nem lehet minden esetben elkülöníteni a megtörtént, valós eseményeket és a pusztán az anekdota szintjén továbbhagyományozódó történeteket. Éppen ezért ez a szempont irrelevánssá válik, a lényeges momentum az, hogy Margalits a lapalji jegyzetekben megadja a szólások magyarázatát, értelmezését. Ezek nélkül számos frazéma teljes egészében érthetetlen lenne a mai olvasó számára. Az ilyen információk nem csupán az egyes szólásoknak, hanem az egész gyüjteménynek többletértéket nyújtanak, megvilágíthatják az idővel elhomályosult (vagy el nem homályosult) frazémák keletkezésének körülményeit. Ha a korabeli adattárak gyakorlatát tartjuk szem elött, azt látjuk, hogy például Erdélyi János - mintegy szócikké formálva a frazémát - közvetlenül az említés után adja meg az értelmezést, használati körülményt; Margalitsnál viszont mindez lapalji jegyzetben szerepel. A szerző e jegyzeteknek többféle típusával egészíti ki a szólásgyüjteményt: helyenként rövid, pár szóból álló értelmezést, kiegészítést ad: pl. Ez igazi hideg konyha. (Az az hideg, érzéketlen leány.) Nem fél a német, hogy elveszik a gatyáját. (A bácskai németek nem hordanak gatyát.). A lapalji jegyzetek egy másik csoportjában nemcsak értelmez, hanem a szólás használati körülményét, pragmatikai jelentését is megadja: pl. Ebböl sem lesz énekes halott. (Azaz, nagyobb, fényesebb temetés. A fenti közmondás értelme: Ebböl sem lesz valami nagy dolog.). Helyenként nemcsak értelmező magyarázatot, hanem anekdotát, mondát is kapcsol a frazémákhoz. Az anekdotával, adomával ${ }^{18}$ ellátott frazémában előfordulhat személynév: Feltette az Orbán

\footnotetext{
${ }^{18} \mathrm{Az}$ ÉKSz. adatai szerint az adoma és az anekdota szó jelentése annyiban különbözik, hogy az anekdota közismert személyről szóló adoma, egyébként mindkettő élőszóban terjedő rövid, csattanós, vidám történet.
} 
süvegét. (Dóczy Orbán egri püspök szolgája, 1490-ben II.ik Ulászló koronázása alkalmával oly részeg volt, hogy püspöki urának süvegét, melyet tartania kellett volna, feltette saját fejére.).

Lokális érvényű, szűk közösséget érintő esemény, magatartásforma metaforikus alkalmazása található a Stocek kivetközött szólás esetében: (Stocek a pesti központi papnöveldéböl kilépett, ezt egy kivételével mindannyian tudták, midőn végre ez is megtudta nagy sebbel-lobbal sietett ezt ujságképen a többinek elmondani.). Esetenként Margalits magyarázata sem eléggé világos, feltehetően ő maga is más gyüjtőktől vette át a kérdéses adatot. Ugyanakkor számos érdekes müvelődéstörténeti adatra is rábukkanunk a lapalji jegyzetekben: pl. a Szent Miska elnevezést így kommentálja: (1818-ban egész Bácskát egy Miska nevü rajongó szabó járta be, a nép processióval kisérte; pályáját a zombori börtönben végezte.).

Gyakoriak a meghatározott személyekkel kapcsolatos szóláshasonlatok is: Verik mint Pilátust. (Nagy csütörtökön a délutáni breviarium után a gyerekek a templom padjait pálcákkal ütögetik.) Előfordul, hogy a valamikori történet egyegy eleme, akár egy jellegzetes mondata önállósul, szemantikailag konnotatívvá válik, s így a második jelentésszint hagyományozódik (vö. R. Molnár 1994, 85). Ennek kitünő példája Margalits gyüjtésében az El a kanálissal frazéma, melynek hátterében a Zombornál épülő Ferenc-csatorna terve volt, amikor is a gyerekek miatt a zombori városi tanács a csatorna építését a várostól messzebbre kérte. Ez a kiszólás, felkiáltás később feltehetően már csak a tiltás képzetét vitte tovább, a denotatív jelentés elhomályosult.

Számos érdekes történet bontakozik ki ily módon a lábjegyzetekből: a XIX. századi Bácska úri életvitelének mozzanatai, a korabeli egyházi emberek magatartása, a tágabb politikai események bácskai lecsapódása, az egyszerü vidéki ember történetei egyaránt felvillannak.

\section{Összegzés}

A bácskai szólásgyüjtemény és az 1896-ban kiadott nagylélegzetü adattár összehasonlítása során megállapíthatjuk, hogy Margalits nem automatikusan, változtatás nélkül építette be a későbbi gyüjteményébe a bácskai anyagot, hanem némileg rendszerezve, a vezérszavakat kiemelve, s ami a legszembetűnőbb, szelektálva mentette át ezt a szólásanyagot; főként a frazeológia területére került folklóranyagot „rostálta át”: az élőnyelvhez szorosan kötődő elemek - pl. a helyzetmondatok, kiszólások, mondókák stb. - maradtak ki: pl. Kis kését nekie. A felül már ihatik kend, ehetik kend, alhatik kend. Az ilyen 
típusú frazémák erőteljes szituatív kötöttségét a szerző is érzékelhette, s ezért nem sorolta be őket a közmondások, illetve a „közmondásszerű szólások” közé. E kis terjedelmü szólásgyüjtemény fontos dokumentuma a korabeli élőnyelvnek, a népi-táji nyelvhasználat sajátosságainak, ugyanakkor számos hely- és művelődéstörténeti értéket is rejt.

\section{Irodalom}

Bene Annamária. 2004. Margalits Ede frazeológiai gyüjteményéről. Magyar Nyelv (2): 206-209.

Forgács Tamás. 2007. Bevezetés a frazeológiába. Budapest: Tinta Könyvkiadó.

Gulyás Pál 1940: Margalits Ede. Irodalomtörténet (29): 142.

Hadrovics László. 1995. Magyar frazeológia. Budapest: Akadémiai Kiadó.

Kovács Erzsébet. 2014. Előszó. In Margalits Ede-Kovács Erzsébet: Magyar-latin közmondásszótár. Budapest: Tinta Könyvkiadó.

Kőhegyi Mihály-Solymos Ede. 1973. Észak-Bácska földrajzi nevei Pesty Frigyes kéziratos Helynévtárában. Baja.

Margalits Ede. 1877. Bácskai közmondások és szólásmódok. Baja: nyomatott Nánay Lajosnál.

R. Molnár Emma. 1994. Idiómák adomákból. In Bárczi Géza centenárium, szerk. Békési Imre, H. Tóth Imre. 77-86. Szeged: MTA Szegedi Területi Bizottsága.

O. Nagy Gábor. 1982. Magyar szólások és közmondások. Budapest: Gondolat.

Papp György. 1989. Szóláskincsünk mint nyelvi érték. Hungarológiai Közlemények (3): 507-511.

Papp György. 2007. A vajdasági frazeológiai korpusz szerkezeti, adattári vonatkozásai. In Délvidék/Vajdaság. Társadalomtudományi tanulmányok, szerk. Papp Richárd. 70-109. Zenta: Vajdasági Magyar Mủvelődési Intézet.

Rajsli Ilona. 2013. Frazémavariánsok egy helyi jellegü korpuszban. Hungarológiai Közlemények (4): 1-10.

\section{TRAITS OF THE BÁCSKA REGION IN EDE MARGALITS'S EARLY COLLECTION OF PHRASEMES}

Ede Margalits's Bácskai közmondások és szólásmódok (Proverbs and Idioms from Bácska) was published in Baja in 1877, and this publication was the forerunner of the author's later monumental volumes of proverbs and idioms. This small, early collection indicates the professional and scholarly attitude of Margalits when focusing on the compilation of phrasemes. In the introduction the author presents the relevant 
principles of compiling and editing he is guided by, outlining at the same time the vision of a nation-wide collection. Unlike his practice in the later volumes, the idioms follow each other in strict alphabetic order in this early publication, and thus there are no key words in it. In this study, alongside presenting this volume of phrasemes from Bácska, we endeavour to highlight the distinctive local features of the idioms with regional attachment: such as dialectal phenomena, the occurrence of dialectal words, toponyms in idiomatic expressions, the presence of anecdotal phrasemes related to a place and the diversity of ethnic stereotypes. Margalits, just like János Erdélyi, also explains the less familiar phrasemes, and in the cases of the local ones tells of the event (real or alleged) which set off the phraseme, enriching thus with a great number of very valuable - local - anecdotes the local and cultural history of the region.

Keywords: phrasemes, diachronous phraseology, Bácska, regional attachment, Ede Margalits

\section{MOTIV BAČKE U PRVOJ ZBIRCI FRAZEOLOŠKIH IZRAZA EDEA MARGALIČA}

Zbirka Edea Margaliča pod naslovom „Poslovice i izrazi iz Bačke“ objavljena je 1877. godine u Baji i ujedno se može smatrati osnovom za njegov kasniji monumentalni poduhvat vezan za frazeološke izraze. Ova malena zbirka nagoveštava stručni i naučni pristup Margaliča, koji se u svom stvaralaštvu okreće prikupljanju frazema. Margalič u uvodu objašnjava principe koji su za njega relevantni prilikom prikupljanja i uređivanja građe, ujedno predočava i viziju zbirke nacionalnih razmera. Za razliku od kasnijih baza podataka, u ovom izdanju se izreke još navode po abecednom redu, bez navođenja odrednica. Margalič želi da u zbirci izraza vezanih za teritoriju Bačke istakne lokalna obeležja (dijalekatske pojave, teritorijalnu leksiku, toponime, semantiku anegdotskih izraza vezanih za ovaj predeo, šarenolikost etno-stereotipa). Poput Janoša Erdeljija, i Margalič često objašnjava slabo poznate fraze, a u slučaju izraza lokalnog karaktera, kazuje i događaje (istinite ili izmišljene) koji su indukovali nastanak frazema, navodi nekoliko veoma vrednih anegdota, obogaćujući na taj način lokalnu i kulturnu istoriju pojedinih naselja i čitave regije.

Ključne reči: frazeološki izrazi, dijahrona frazeologija, lokalni motivi, Bačka, Ede Margalič 